\title{
The Link between Speech Mastery and Writing Achievement: The Case of Madrasah Students in South Sumatera
}

\section{Shohibul Kahfi Alam Putra}

sshohibul99@gmail.com

A Teacher of Excellent Learning Center Palembang, South Sumatra, Indonesia

\begin{abstract}
This study investigated the link between students' parts of speech mastery and their achievement in writing skill. This study was aimed at finding out whether or not there was any significant link and significant influence among the two variables. The population of the study was tenth grade Madrasah students in South Sumatera. There were 330 students from five classes as the population in this study. However, 96 students were taken as the sample of this study. There were two variables involved in this study, students' parts of speech mastery (variable X), and writing achievement (variable Y). The score of parts of speech mastery was taken from multiple choice questions, while the student' writing achievement was taken from the test which was scored based on experts' judgment. Based on the data analysis, it was found that the $r$-obtained (.293) was higher than $r$-table (.200). Then, the level of probability $(p)$ significance (sig.2-tailed) was .443. It means that $p(.004)$ was lower than .05. Thus, null hypothesis $\left(\mathrm{H}_{0}\right)$ was rejected and the alternative hypothesis $(\mathrm{Ha})$ was accepted. Based on the findings, it was concluded that there was significant link between students' parts of speech mastery and their writing achievement. The obtained R-square was .083 indicated that students' parts of speech mastery was likely to contribute with $8.3 \%$ contribution and to affect writing achievement.
\end{abstract}

Keywords: madrasah students, parts of speech mastery, writing achievement

\section{Introduction}

For hundreds of years, English has already become an international language and widely accepted in many sectors in daily activities such as in business, politics, culture, and especially in education. Nowadays, having a good English language skill is demanded as the means of international communication spoken among foreign language speakers (Abrar, Mukminin, Habibi, Asyrafi, Makmur, \& Marzulina, 2018; Susilo, 2015; Richard, 2006; Oommen, 2012).

In Indonesia, English is the first foreign language and becomes a subject that has been taught from Elementary School up to Higher Education. Yet, since the 2013 Curriculum applied, Kemendikbud states that English can be taught in elementary schools as the additional subject instead of the compulsory one (Herizal \& Afriani, 2015; Nisa, 2015; Yusuf, 2015; Abdurrahman, 2014). According to Carolina (2017), regarding to its status in education, English is a "complicated subject" taught in Indonesia. Besides, according to Pitaloka (2014), the allocation time for English subject is limited at schools. In these conditions, all of the students should be sought to have a good competence in English language learning which is marked by great achievement. 
Based on School-based Curriculum (KTSP) 2006 and the 2013 Curriculum, teachers should aim at developing four skills of learners' ability both productive skills (i.e. speaking and writing) and receptive skills (i.e. writing and reading). Hyland (2009) stated that among four skills, writing is a productive skill which plays an important role in reflecting social identity. Chuy, Scardamalia, \& Bereiter (2012) said that as a system to record language meaning and word symbol, the importance of writing in the development of $21^{\text {st }}$ century dispositions and skills involve reorganizing and generating new knowledge to students which brings many benefits in social life. As stated by Klein \& Boscolo (2016), Firstly, writing is a good way in language productions, a psychological process, and a practice with different functions/genres related to various socio-cultural contexts. Second, writing is also an essential tool to support other skills. That is, if a student has good writing ability, they likely can speak, listen to, and read the text more effectively. Third, in line with Crossley and McNamara (2016), writing is a way to provide students with effective instruction that helps them meet expectations. In other word, writing is important to academic success and one of requirements to participate both in academia and workplace. Fourth, in agreement with Saputra and Marzulina (2014), writing skill is very basically essential skill in learning a foreign language which includes the development of an idea, knowledge, and experience.

English writing is not a new anomaly assumed as difficult subject by the students in any nations including Indonesia. Q. Yusuf, Y. Q. Yusuf, B. Yusuf, and Nadya (2017) state that it is likely that the EFL (English as a Foreign Language) students surely encounter problems in learning the language. Alsamadani (2010), for example stipulates EFL/ESL writing as a difficult, complex and challenging process. In line with it, Lestari and Holandyah (2016) added that the complexity comprises word choices, grammar, punctuation, spelling, coherence, and still many others. Besides, Astrid, Rukmini, Sofwan, and Fitriati (2017) adds that anxiety appears as learners' inadequacy in the writing skill, which has long been recognized as a barrier in second language learning context both for students and teachers. According to Arib (2017), it will trigger students' lack of motivation which is shaped by a variety of factors like family inputs, teacher inputs, and school inputs from the anxiety itself. Therefore, Habibi, Wachyuni and Husni (2017) explained that the students feel that they do not have interest in writing any topic, perhaps in unfamiliar genres, and without the necessary information.

Nowadays, Indonesia is facing great challenge to develop its society's writing competence. In terms of delivering information, writing is related to a national development, that is, the more a nation has had or published scientific journal, the more human index increases. For instance, as the lack of published study pertaining to Indonesia's TIMSS performance, the country's ability towards the international competence is declining (Luschei, 2017). Furthermore, on Scopus, Sindo records that Indonesia was in the $61^{\text {st }}$ position with 25.481 publications. Compared to other ASEAN countries, Indonesia is still so far away to compete Malaysia which is aiming to be a fully industrialized with highly knowledgeable and skillful teachers by the year of 2020 (Azkiyah \& Mukminin, 2017; Ghazali, Rabi \& Wahab, 2017). Meanwhile, Malaysia was positioned in $37^{\text {th }}$ ranked with 125.084 publications and Singapore was in $32^{\text {nd }}$ rank with 171.037 publications.

At least there are two solutions which can solve problems in Indonesia to strengthen the writing ability, so it will also trigger the new researchers to be confident to publish their scientific work and can affect the students' writing achievement. According to Dutwin (2010), the solutions are: (1) mastering parts of speech which cannot be irrespective from the term 
"Grammar" as one way to understand a language through thinking of words as having a grammatical name, called parts of speech, and a function name that tells what it does in the sentence and it existed in any language, and (2) students need to learn more, so they will simultaneously write paragraph writing and know the components that need to be the priority, such as language use, grammar, and vocabulary usage (Hayes \& Flower, 1980). Therefore, it is necessary that the students understand both content and function words (as in grammar) in sentences to enhance students' ability in writing sentences appropriately.

As the element of grammar, parts of speech are very useful in order to make the arrangement of words in a correct sentence. Seefer (2011) stated that parts of speech itself is the basic types of words that English has, by means, they are the words used to construct sentences. Generally, Mary and Carolyn (2011) explained there are eight classifications in English parts of speech such as noun, verb, adjective, adverb, pronoun, preposition, conjunction and interjection. From those classifications, all of words in English can be easily grouped and learned based on their functions.

There are so many advantages of understanding parts of speech: (1) learners will be able to use them in various contexts and traditional terms to describe the different words that are used to form sentences (Richard, Jhon \& Heidi 1992) and (2) parts of speech will intensify learner's comprehension during learning exposure; It means, every word in English language functions, at least one parts of speech help students analyze both grammar and meaning (Simon \& Schuster, 2003).

Based on the preliminary study conducted by giving ten multiple choice questions and a paragraph writing test for students, and interview with a teacher of English in the representative school, some problems were found in students' writing. From multiple choice test, it was found that students found it difficult to differentiate the words especially in parts of speech. It can be seen from their scores in general. Approximately, each student answered correctly only 6 out of 10 questions. Moreover, the results revealed that most students could not answer the third and ninth questions (i.e. conjunctions) which possibly could be the most difficult one.

The result of multiple-choice test was also equivalent to students' score in writing a paragraph about "Home" in which there were many aspects to assess that reflected their performance such as language use, vocabulary, prepositions, fragments, and meaning that were still confusing and obscuring. From the interview itself, the teacher said that the students were actually enthusiastic to write based on their willingness but their competence and the knowledge especially about parts of speech were still low. From those evidence, it can be inferred that students need to deepen their knowledge about parts of speech. If once they can differentiate the eight of them (i.e. noun, adjective, verb, adverb, conjunction, interjection, pronoun, and preposition), they will be easy to construct sentences prior to their grammar knowledge.

Actually, some researchers have been exploring related variables or related previous studies. For instance, a study conducted by Rifani (2013) entitled "Study on correlation between vocabulary mastery and writing achievement of the first-grade students of SMK NU Banjarmasin School year 2012 / 2013" showed that there was a significant correlation between students' vocabulary mastery and students' writing achievement. Besides, in Sariatun' study (2010) entitled "The correlation between English vocabulary mastery and students' writing ability of the eight grade students of SMPIT Rahmatan Lil' Alamin Seloaji Babadan Ponorogo in the academic year of 2009/2010", the results indicated that there was a high and significant correlation between the two variables". 
This current study investigated the link and explored the influence between students' parts of speech mastery and their achievement in writing skill. The problems in this study were: (1) was there any significant correlation between parts of speech mastery and writing achievement of the tenth grade students in one madrasah in South Sumatera?, and (2) Did parts of speech mastery significantly influence writing achievement of the tenth grade students in madrasah in South Sumatera?.

\section{Literature Review}

\section{The concept of parts of speech}

Parts of speech normally refer to the basic types of words which English language has, for example, certain words in English have plural form (e.g. nouns, adjectives, articles, prepositions, etc.). According to Pakhomov, Coden and Chute (2005), parts of speech can be classified into large classification containing other words with similar characteristics. Typically, parts of speech are associated with different semantic types: verbs tend to express events; adjectives tend to express states, etc. For this reason, a derivational process which changes the syntactic category of a word generally involves some semantic effects as well. But according to Kroeger (2005), it is not impossible to find examples of category of parts of speech that do not seem to involve any significant change of meaning. Most of the properties of phrasal affixes have "normal" affixes: they are always attached to another word; do not fit into any of the established lexical categories (i.e. Content words) for the language; and tend to express grammatical (i.e. functional words) rather than lexical meanings. However, Kroeger (2012) states that unlike normal affixes, they are "promiscuous" in their attachments, meaning that they may attach to words of almost any category.

There are eight parts of speech in general explained here which are comprised of noun, adjective, verb, adverb, conjunction, interjection, preposition, and pronoun. In fact, there are a lot of classifications of parts of speech which depend on the language and experts' theories. For instance, many linguists argue about the ninth part of speech, that is, article (a, an, and the) since it precedes and modifies nouns, so most grammarians put it as the adjective. Here are the categorizations of the eight parts of speech in English:

Nouns refer to a person, place, or thing. In addition, nouns name qualities, feelings, concepts, activities, and measurement. Nouns can be proper or common noun. Azar (2006) states that proper nouns are capitalized, and common nouns are not. As an open word class, new nouns are being devised almost every day. It seems, nouns are by far the most numerous word class; they also tend to make up more of a text than other open word classes.

Pronouns are words used in place of nouns. According to Azar (2006), pronouns mean that they have the same meaning as nouns. In other words, it can be defined as a word that stands for a noun, or a noun phrase, or something relating to noun. Besides, pronoun is a close word class and the amount is quite small. Pronouns usually contain less specific words. Pronouns are usually used for variety and efficiency in writing.

Verbs are the main part of sentences in English. Marry (2011) states that most verbs are action words. They tell what people, animals, or things are doing. Verbs are classified in an open word class. In terms of grammar verbs are the most important word class because they are the 
central element in clauses. Each full clause must have a verb, and it determines what other elements will be present.

Adjectives, words that describe nouns or pronouns are called adjectives. In grammar, adjectives modify nouns. The word "modify" means change a little. It gives a little different meaning to a noun. Adjectives come before nouns.

Adverbs, words that modify (describe or limit) verbs, adjectives, or other adverbs are defined as adverbs. It tells about an action, or the way or something that has been done. A lot of adverbs end in -ly. Adverbs are an open word class. They consist of a number of sub-classes, some of which are only loosely connected to the others (for example, the intensifiers described above). They have been called a 'ragbag' - a place for putting unwanted things. Isolated systems of words, such as "yes" and "no", "please", and "not", are usually included in adverbs, though they have little in common with them. As a result, David (2007) states that adverbs are much harder to define than other word classes.

Prepositions, according to David (2007), prepositions join nouns and pronouns to other words in a sentence. As the word itself suggests (pre meaning "before"), a preposition is a word in a position before its object. The object of a preposition is a noun or pronoun. Some prepositions tell you about position or place.

Conjunctions, words that connect other words or groups of words are conjunctions. The most common conjunctions are and, but, or, and nor. These are called coordinating conjunctions because they join equal (coordinate) parts of sentences. Just what David (2007) says that conjunctions are a closed class; their function is to join two clauses together and show the relationship meaning between them.

Interjections, typically, words expressing strong feelings are interjections. Marry (2011) claimed that interjections are words that express a sudden, strong feeling such as surprise, pain, or pleasure. Interjections standing alone are followed by exclamation marks.

\section{The concept of writing achievement}

Achievement means the students' mastery of a particular syllabus or the material taught in the class. Thus, claimed by Jesson (2013), writing achievement is the accomplishment of doing specific writing material such as a paragraph essay, story, fable, legend, graphic fiction, etc. Writing achievement is also defined as the student's success in achieving English writing through certain learning process. The result of this achievement is presented in a list of students' writing scores as a reflection of instructional objective of writing skill from senior high school syllabus to write a simple paragraph.

\section{Methodology}

\section{Design}

In conducting this study, correlational study was used in terms of explanatory study design to find out the correlation between variables, explain and interpret the results that may appear. A correlational study was a scientific study in which I investigated associations between variables. Cresswell (2012) states that correlational designs can predict scores and explains the relationship among variables. Moreover, Fraenkel, Wallen, and Hyun (2012) state that although investigations 
of more than two variables are common, but correlational investigation still has possibility to know the relationship between only two variables.

\section{Site, sampling, and participants}

The populations of this study were tenth grade students of Madrasah in South Sumatera. Meanwhile, I drew the sample by using convenience sampling technique. Just as Fraenkel, Wallen, and Hyun (2012) claim that a convenience sampling is a group of individuals who are (conveniently) available for the study. The sample was taken by using convenience sampling as the school was restricted by the number of classes, so there were only three available classes; $\mathrm{X}$ MIA 2, X IIS 3, and X IIS 4. There were 96 students (none of the students was absent).

\section{Data collection and analysis}

To collect the data, two kinds of tests were used. To find out the students' parts of speech mastery and students' writing performance, the multiple-choice questions test and a paragraph writing test were used. The multiple-choice test was a ready-made test as it was compiled from many TOEFL books and from other resources on the internet. The validity and reliability had been checked by conducting a try-out test at one school with the same grade/rank. The multiplechoice questions consisted of 40 items and each item had four options (a, b, c, and d) with one correct option. Sudjiono (2009) states that multiple choice test items are usually set out in such way that candidate is required to select the answer from a number of given options, where there is only one of which is correct. The total number of the test items were 40 for each student. The test took about 50 minutes to comprehend and to answer the questions. For the writing test, the students were instructed to write a paragraph writing about "Yourself" which was assessed by using Weagle's rubric as it is also in line with the syllabus and appropriate to measure students' writing in English for high school. For this section, students were only given 45 minutes to write.

Firstly, the data from the correct answer were analyzed in the form of percentages to determine the students' parts of speech mastery score. Secondly, the students' writing test were analyzed by the three raters, those who validated the writing test, by using the rubric of paragraph writing. There are five aspects of the writing scoring system and the category and the scale of each aspect has levels and various maximum scores. As a result, as there are three raters, the total points from them determined the students' writing achievement.

Furthermore, to analyze the data obtained from the multiple choice test and the student's writing test, the Statistical Package for Social and Science (SPSS) computer program was employed in order to see the correlation and to know the significant influence between the two variables. To find out the correlation between parts of speech mastery and writing achievement, Pearson - Product Moment Correlation Coefficient was used. Besides, regression analysis was used in order to know the contribution of parts of speech mastery for writing achievement.

\section{Findings and Discussion}

\section{The result of parts of speech mastery}

The descriptive statistical analysis of parts of speech mastery showed that the maximum score of the participants overall in parts of speech test was 90 and the minimum score was 40 . 
The mean score was 72.47 and the standard deviation was 10.40 . This mean score indicated that the level of mastery of participants was considered as fair category. The descriptive statistics analysis is as follows:

Table 1. Descriptive statistics of students' parts of speech score

\begin{tabular}{cccccc}
\hline & N & Minimum & Maximum & Mean & Std. Deviation \\
\hline Parts of speech & 96 & 40.00 & 90.00 & 72.4740 & 10.40960 \\
Valid N (list wise) & 96 & & & & \\
\hline
\end{tabular}

\section{The results of writing achievement}

The descriptive statistical analysis of writing achievement showed that the maximum score of participants' overall in writing test was 86 while the minimum score was 40 , the mean score was 58.15 and 11.01 as the standard deviation of the students' writing test. This mean score indicated that the level of writing achievement of participants was in the level of fair category. The descriptive statistics of students' writing achievement score could be seen in Table 2:

Table 2. Descriptive statistics of students' writing achievement score

\begin{tabular}{lccccc}
\hline \multicolumn{1}{r}{ Variables } & N & Minimum & Maximum & Mean & Std. Deviation \\
\hline Writing achievement & 96 & 40.00 & 86.00 & 58.1502 & 11.01526 \\
Valid N (list wise) & 96 & & & & \\
\hline
\end{tabular}

\section{The result of normality and linearity}

The data are interpreted normal if $\mathrm{p}>0.05$. If $\mathrm{p}<0.05$, it means the data are not normal. In this study, Kolmogorov-Simonov was used to analyze the normality of the data. The results of normality test indicated that the data from each variable were all normal and appropriate for data analysis with coefficients .064 for parts of speech mastery and .11 for writing achievement.

For linearity test, the deviation of linearity was obtained. If the probability score is more than .05, the two variables are linear. The results showed that, the deviation from linearity between parts of speech mastery and writing achievement was .502. In other words, the data were linear.

\section{The correlation between parts of speech mastery and writing achievement}

In this section, I tried to answer the first study problem by analyzing the result of descriptive statistics for parts of speech mastery and writing achievement. Based on Pearson Product Moment Correlation Coefficient, the results indicated that there was a significant correlation between parts of speech mastery and writing achievement. The correlation coefficient or the $r$-obtained was (.293) which was higher than $r$-table (.200). Then the level of probability 
(p) significance (sig.2-tailed) was .004. It showed that $p$ (.004) was lower than .05. Thus, there was a significant correlation between parts of speech mastery and writing achievement.

Table 3. The correlation between parts of speech mastery and writing achievement

\begin{tabular}{llll}
\hline & & \multicolumn{1}{c}{$\begin{array}{c}\text { Parts of Speech } \\
\text { Mastery }\end{array}$} & $\begin{array}{c}\text { Writing } \\
\text { Achievement }\end{array}$ \\
\hline Parts of Speech Mastery Pearson Correlation & 1 & $.293^{* *}$ \\
& Sig. (2-tailed) & & .004 \\
& $\mathrm{~N}$ & 96 & 96 \\
\hline Writing Achievement & Pearson Correlation & $.293^{* *}$ & 1 \\
& Sig. (2-tailed) & .004 & \\
& $\mathrm{~N}$ & 96 & 96 \\
\hline
\end{tabular}

\section{The influence of parts of speech mastery on writing achievement}

The results of analysis indicated that the students' parts of speech mastery influenced their writing achievement significantly with $t_{\text {value }}(2.916)$ was higher than $t_{\text {table }}(1.290)$ with sig. value (.004) which was lower than its probability (0.05). Therefore, there was a significant influence between students' parts of speech mastery and writing achievement.

Table 4. The regression analysis of parts of speech mastery and writing achievemen

\begin{tabular}{|c|c|c|c|c|c|c|}
\hline \multirow{2}{*}{\multicolumn{2}{|c|}{ Model }} & \multicolumn{2}{|c|}{$\begin{array}{l}\text { Unstandardized } \\
\text { Coefficients }\end{array}$} & \multirow{2}{*}{$\begin{array}{l}\text { Standardized } \\
\text { Coefficients } \\
\text { Beta }\end{array}$} & \multirow[b]{2}{*}{$\mathrm{T}$} & \multirow[b]{2}{*}{ Sig. } \\
\hline & & $\mathrm{B}$ & Std. Error & & & \\
\hline \multirow[t]{2}{*}{1} & (Constant) & 56.669 & 5.462 & & 10.375 & .000 \\
\hline & $\begin{array}{l}\text { Parts of speech } \\
\text { mastery }\end{array}$ & .269 & .092 & .288 & 2.916 & .004 \\
\hline
\end{tabular}

a. Dependent Variable: Writing Achievement

Based on the result of the analysis, it revealed that $R$ Square $\left(\mathrm{R}^{2}\right)$ was 0.83 . It indicated that the students' parts of speech mastery gave significant effect in the level of $8.3 \%$ toward writing achievement, and $91.7 \%$ was other unexplained factors. The details were as follows:

Table 5. Model summary

\begin{tabular}{|c|c|c|c|c|}
\hline Model & $\mathrm{R}$ & R Square & $\begin{array}{c}\text { Adjusted R } \\
\text { Square }\end{array}$ & Std. Error of the Estimate \\
\hline 1 & $.288^{\mathrm{a}}$ & .083 & .073 & 9.90986 \\
\hline
\end{tabular}

a. Predictors: (Constant), parts of speech mastery 
In order to strengthen the value of this study, the interpretations were made based on the results of data analysis. According to the findings, there was a significant correlation between the students' parts of speech mastery and the writing achievement. Also, there was a significant influence of parts of speech mastery on the writing achievement.

\section{Discussion}

From the result of Pearson Product Moment correlations, it was found that there was a significant correlation between the students' parts of speech mastery and the writing achievement of the tenth grade students of Madrasah in South Sumatera with $r$ - .288. This indicated that students' parts of speech mastery had a relation to their achievement in writing. There were some possible explanations to support this finding. First of all, based on the rubric used in writing achievement (Weigle, 2002), there are 5 categories that should be mastered by students in writing; (1) content (30\%), (2) organization (20\%), (3) language use (25\%), vocabulary (20\%), and mechanics (5\%). Directly, parts of speech also played an important role in writing achievement as each word in English belongs to one of the eight parts of speech. Each word was also either a content word (information and meaning) i.e. nouns, verbs, adjectives, and adverbs or a function word (necessary words for grammar) i.e. pronoun, conjunction, preposition, and interjection. The eight parts of speech themselves cannot be irrespective from vocabulary as each word in dictionary can be classified into one or more parts of speech and it comprises contributions up to $20 \%$ towards writing achievement. Therefore, it indicated that the more students master parts of speech the better their writing will be. According to McKeown (1993), vocabulary is very fundamental in writing and in instructional practice to have students look words up in a dictionary, copy or restate definitions, and then create sentences using the words. However, students often cannot understand the definitions that dictionaries, even children's dictionaries, present.

Secondly, the majority of the students have already been familiar with parts of speech and writing genre given by teacher over five years of studying English in junior high school even in elementary school. Then, in their previous class (tenth grade), the students learned about parts of speech and a paragraph writing. In one hand, many students in tenth grade, especially in science class, took course after their school and it can help the students improve their English achievement and that influenced their grammar in the aspect of parts of speech and writing achievement. Last, time allocation and the topic chosen from the test was suitable to their conditions or their real lives. In this test, the students described something real and general. They did not feel hard to face this situation and think too much.

Even though the result of this study admitted that students' parts of speech mastery had a significant correlation with students' writing achievement, it should not simply be ignored if there were some students who still had difficulties in learning parts of speech As stated above, the result of students' score in parts of speech test showed that the mean score indicated that the level of student's mastery in parts of speech of the tenth grade students in Madrasah in South Sumatera was enough $(\mathrm{M}=72.31$; $\mathrm{SD}=10.29)$. While, the result of students' score in writing test showed that the mean score of the writing test of this study indicated that the level of students' achievement in a paragraph writing was in average $(\mathrm{M}=58.15 ; \mathrm{SD}=10.01)$. The majority of students $(45.8 \%)$ had very poor writing achievement in a paragraph writing. It 
indicated that they still had difficulties in writing even though they had good mastery in grammar.

Furthermore, the lack of student's interest was the problem of their writing, the students had difficulties in organizing their ideas. They were confused on how to start to write. Besides, the students lacked of vocabulary mastery and it made students difficult to find the word choice and the use of that word in a sentence, that sometimes it made the meaning of that sentence obscured and difficult to understand. This situation is supported by some experts; First, according to Dyrud, Worley, and Flatley (2005), although writing is an essential skill, many students at high school are not interested in it. They are even not aware of the importance of writing skill in their learning. Indeed, language use is not only one of the dominant factors that influence students' writing achievement. The students also need to learn about the strategies that can be used to write more easily. For example, brainstorming, guided tasks and etc. According to Harmer (2004), for many years, teaching writing focused on the written product rather than on writing process. In other words, the students' attention was directed to the "what" rather than "how" the text is constructed. However, we also need to concentrate on the process of writing and regarding to this, there are some strategies that we need to consider: (1) the way we get the students' plan, before getting the students to write we can encourage them to think about what they are going to write by planning the content first.; (2) the way we encourage them to draft, reflect and revise. One way to encourage in drafting, reflecting, and revising is to have the students involved in elaborative writing; (3) the way we response to the students. In order to make a process in writing approach work well, some teachers may need to rethink the way in which they react to their students' work.

In addition, to look deeper into the process of the study, I perceived there were some factors affected the results of the present study and made the result of parts of speech knowledge and writing test not balanced, such us the uncontrolled situation in which the tests were completed, for examples, noise distraction, discussing questions and responses with other respondents to complete the test in the class, honesty and seriousness in filling out the tests, or even bad respondents' health condition and etc. The result of this present study is in line with the study of Harmer (2004). This study found that there was high significant correlation between students' parts of speech mastery and writing achievement and also there was a significant influence between those variables. It was proved by the obtained value $\left(\mathrm{r}_{\text {calculated }} 0.76\right)$ that was higher than r-table (0.35). Then, it was implied that an increasing grade in parts of speech mastery had relationship with an increasing grade in writing achievement. Moreover, it is also in line with McKeown (1993) who found that there was significant correlation between students' parts of speech mastery and writing achievement with $r$ correlation 0.401 . It can be predicted that if the student gets high score in parts of speech, they also will get high score in writing achievement, and vice versa.

In short, the total contribution of students' parts of speech mastery and their writing achievement showed significant correlation and influence. However, the unexplained factors also had contribution on students' writing achievement. The findings of the study may have some benefits for students, teacher of English, and next researchers. 


\section{Conclusions}

Based on the findings, it could be concluded that, first, there was a weak correlation between two categories of the variables meaning that students' parts of speech mastery had a weak correlation with their writing achievement. Second, based on form the regression analysis, it was found that there was a significant influence of students' thinking styles and writing achievement. Also this study had some pedagogical implications for foreign language teacher, students, and next researchers.

\section{References}

Abdurrahman, M. (2014). Pendidikan bagian akber kesulitan belajar. Jakarta, Indonesia: Rineka Cipta.

Abrar, M., Mukminin, A., Habibi, A., Asyrafi, F, Makmur, \& Marzulina, L. (2018). If our English isn't a language, what is it? Indonesian EFL student teachers' challenges speaking English. The Qualitative Report, 23(1),129-145. Retrieved from http://nsuworks.nova.edu/tqr/ vol23/iss1/9

Alsamadani. (2010). The effect of thinking styles on EFL learners' language learning strategies in reading comprehension. International Journal of Language Learning and Applied Linguistics World (IJLLALW), 6(4), 53. Retrieved from https://onlinejournal.unja.ac.id/index.php/irje/article/ view/4333

Arib, A. W. (2017). Do family backgrounds control students' motivation and achievement in learning a foreign language? the case of one Islamic senior high school in Jambi. Ta'dib: Journal of Islamic Education, 22(1), 1-38. Retrieved from http:// jurnal.radenfatah.ac.id/index.php/tadib/article/ view/ 1622

Astrid, A., Rukmini, D., Sofwan, A., \& Fitriati, S. W. (2017). The analysis of students' engagement to writing feedback activities viewed from students' writing anxiety. International Journal of English and Education, 6(1), 86-107. Retrieved from http://jfl.iaun.ac.ir/ article_44922_627ec908874cb71dcc 352092dc9b1e8d.pdf

Azar, S. (2006). English grammar. New York, NY: Pearson Education ESL.

Azkiyah, S. N., \& Mukminin, A. (2017). In search of teaching quality of EFL student teachers through teaching practicum: Lessons from a teacher education program. CEPS : Center for Educational Policy Studies Journal,7(4), 105-124. Retrieved from https://onlinejournal.unja.ac.id/ index.php/irje/announcement/view/32

Carolina, E. S. (2017). Are Islamic Boarding Schools Ready? The Use of the Computer-Based Test in the National Exam Policy for English Subject. Ta'dib: Journal of Islamic Education, 22(2), 44-53. Retrieved from http://jurnal.radenfatah.ac.id/index.php/tadib/article/view/ 1638/pdf

Chuy, M., Scardamalia, M., \& Bereiter, C. (2012). Writing: A Mosaic of New Perspectives. New York, NY: Taylor and Francis.

Cresswell, J. W. (2012). Educational study planning, conducting and evaluating quantitatif and quaitatif study(4th ed). Boston, MA; Pearson.

Crossley, S. A., \& McNamara, D. S. (2016). Say more and be more coherent: Jow text elaboration and cohesion can increase writing quality. Journal of Writing Study, 7(3), 351370. 
David, H. (1964). Testing English as a second language. New York, NY. MC. Graw Hill.

Dutwin, P. (2010). English grammar demystified. New York, NY: McGraw-Hill.

Dyrud, M. A., Worley, R. B., \& Flatley, M. E. (2005). Blogging for enhanced teaching and learning. Business Communication Quarterly, 68(1), 77-80.Retrieved from fromhttp://staffnew.uny.ac.id/upload/132107096/penelitian/1rajar.pdf

Fraenkel, J. R., Wallen, N. E., \& Hyun, H. H. (2012). How to design and evaluate study in education (8th ed). New York, N.Y: McGraw-Hill.

Ghazali, N.H., Rabi, N.M., Wahab, N.A. (2017). Development and validation of an inventory to evaluate teaching strategies for promoting higher-order thinking skills in the teaching of Islamic education. Ta'dib: Journal of Islamic Education, 22(1), 39-49. Retrieved from http://jurnal.radenfatah.ac.id/ index.php/tadib/article/view/1217

Habibi, A., Wachyuni, S., \& Husni, N. (2017). Students' perception on writing problems: A survey at one Islamic university in Jambi. Ta'dib: Journal of Islamic Education, 22(1), 96108. Retrieved from http://jurnal.radenfatah. ac.id/index.php/tadib/article/view/1623

Harmer, J. (2004). How to teach writing. Essex, England: Pearson Education Limited.

Hayes, J. R., \& Flower, L. (1980). Identifying the organization of writing processes. Hillsdale, NJ: Lawrence Erlbaum.

Herizal, \& Afriani, N. (2015). Improving students' descriptive writing text through picture word inductive model (PWIM) strategy for seventh grade of SMP Inaba Palembang. Edukasi: Jurnal Pendidikan dan Pengajaran, 2(1), 25-34. Retrieved from http://jurnal.radenfatah.ac.id/index.php/edukasi/article/view/ 594

Holandyah, M., \& Lestari, A. (2016). The correlation between reading attitude and writing achievement of the eleventh-grade students of SMA Muhammadiyah 6 Palembang. Edukasi: Jurnal Pendidikan dan Pengajaran, 3(1), 45-52. Retrieved from http://jurnal.radenfatah.ac.id/index.php/edukasi/article/view/ 627

Hyland, D. (2009). The practice of English language teaching. China: Pearson educational Limited

Jesson, R. (2013). Accelerating writing achievement. SET: Study Information for Teachers, 3(2), 63-66.

https://www.studygate.net/publication/320881975_Facilitating_language_acquisition_thro ugh_multimodal_instruction

Klein, P. D., \& Boscolo, P. (2016). Trends in study on writing as a learning activity. Journal of Writing Study, 7(3), 311-350. from https://www.studygate.net/publication/320881975_Facilitating_language_acquisition_thro ugh_multimodal_instruction

Kroeger, P. (2005). Analyzing grammar: An introduction. Cambridge, MA: Cambridge University Press.

Kroeger, P. R. (2012). Analyzing grammar. United Kingdom, UK: Cambridge University Press. Luschei, T. F. (2017). 20 years of TIMSS: Lessons for Indonesia. Indonesian Study Journal in Education, 1(1), 6-17. Retrieved from https://onlinejournal.unja.ac.id/index.php/irje/article/ view/4333

Marry, C. (2011). English business. Mason, OH: South-Eastern Cancage Learning.

McKeown, M. G. (1993). Creating effective definitions for young word learners. Reading Study Quartely, 28(1),16-31. doi:10.2307/747814. 
Nisa, A. F. (2015). Improving students' writing skill by using inquiry technique at the eighthgrade students of MTS Negeri 2 Palembang. Edukasi: Jurnal Pendidikan dan Pengajaran, 2(2), 77-86. Retrieved from http://jurnal. radenfatah.ac.id/index.php/edukasi/article/view/599

Ommen, A. (2012). Teaching English as a global language in smart classrooms with Power point presentation. English Language Teaching, 5(12), 54-61. Retrieved from https://bu.univouargla.dz/master/pdf/KAZOUZ_Ismail.pdf?idmemoire $=1721$

Pakhomov, C. C. (2005). Developing a corpus of clinical notes manually annotated for part-ofspeech. International Journal of Medical Informatics, 75(1), 418-429. Retrieved from htpt://epub.cnki.net/grid2008/detail.aspx?QueryID=9\&CurRec=1.

Pitaloka, N. L. (2014). Developing interactive multimedia with local-content-based narrative texts for grade eight. Lingua, Jurnal Bahasa \& Sastra, 15(1), 1-22. Retrieved from http://ejournal.unsri.ac.id/index.php/lingua/article/view/1994

Richard, H. M., \& Denison, D. (2006). A brief history of English language. UK: Cambridge University Press.

Richards, J. C., Jhon P., \& Heidi P. (1992). Longman dictionary of language teaching and applied linguistics. Malaysia: Longman Group UK Limited.

Rifani, M. (2013, August 4). The study on correlation between vocabulary mastery and writting achievement of the first grade student of SMK NU Banjarmasin School year 2012/2013. Retrieved from Http://www.academia.edu.

Sariatun. (2010). The correlation between English vocabulary mastery and writing ability of the English grade student of SMP IT Rahmatan Lil Alamin Babadan Ponorogo in academic year 2009/2010. Retrieved from Http://www.academia.edu.

Saputra, H., \& Marzulina, L. (2015). Teaching writing by using process genre approach to the eighth-grade students of SMP Negeri 22 Palembang. Edukasi: Jurnal Pendidikandan Pengajaran, 2(1), 1-12. Retrieved from http://jurnal.radenfatah.ac.id/index.php/edukasi/article/view/592

Seefer, C. (2011). English business. Mason, OH: South-Eastern Cancage Learning.

Simon, S. (2003). Bulding grammar, usage, and style. New York, NY: Anderson Inc.

Sudjiono, A. (2009). Pengantar statistik pendidikan. Jakarta, Indonesia: PT Raja Grafindo Persada.

Susilo, E. (2015). Teaching vocabulary by using pave strategy to the third-grade students of SDN 182 Palembang. Edukasi: Jurnal Pendidikan dan Pengajaran,2(2), 173-183. Retrieved from http://jurnal.radenfatah.ac.id/ index.php/edukasi/article/view/607

Yusuf, Q., Yusuf, Y. Q., Yusuf, B., Nadya, A. (2017). Skimming and scanning techniques to assist EFL students in understanding English reading texts. Indonesian Study Journal in Education, 1(1), 43-57. Retrieved from https://onlinejournal.unja.ac.id/index.php/irje/article/view/4333 